\title{
CONTAGION AND DOWNSIDE RISK IN THE REIT MARKET DURING THE SUBPRIME MORTGAGE CRISIS
}

\author{
Ming-Chi CHEN a, Hsiu-Jung TSAI ${ }^{\text {b,*, Tien-Foo SING }}{ }^{\text {c, Chih-Yuan YANG }}{ }^{\text {d }}$ \\ a Department of Finance, National Sun Yat-sen University, Taiwan \\ ${ }^{b}$ Department of Finance, National Kaohsiung First University of Science and Technology, 15F., \\ No. 249, Guanghua 3rd Rd., Qianzhen Dist., Kaohsiung City 806, Taiwan \\ ${ }^{c}$ Department of Real Estate, National University of Singapore, Singapore \\ ${ }^{d}$ Department of Finance, Tainan University of Technology, Taiwan
}

Received 23 April 2013; accepted 6 November 2013

\begin{abstract}
This study empirically tests the contagion effects in stock and real estate investment trust (REIT) markets during the subprime mortgage crisis by using daily stock- and REIT-markets data from the following countries and international bodies: the United States, the European Union, Japan, Hong Kong, Singapore, Australia, and the global REIT market. We found a significant and positive dynamic conditional correlation (DCC) coefficient between stock returns and REIT returns. The results revealed that the REIT markets responded early to market shocks and that the variances were higher in the post-crisis period than in the pre-crisis period. Evidence supporting the contagion effects includes increases in the means of the DCC coefficients during the post-crisis period. The Japanese and Australian REIT markets possess the lowest time-varying downside systematic risks. We also demonstrated that the "DCC E-beta" captures more significant downside linkages between market portfolios and expected REIT returns than does the standard CAPM beta.
\end{abstract}

KEYWORDS: Contagion effect; Systematic risk; Downside risk; Time-varying beta; Dynamic conditional correlation (DCC) model

\section{INTRODUCTION}

During the period from March 2007 to 2008, the U.S. financial market experienced an unprecedented financial shock, which spread swiftly to other countries in Europe and Asia. The sharp rise in subprime mortgages in the U.S. in the early 2000 s had been unsustainable and was the precursor to the crisis. One of the most severe financial crises since the Great Depression was triggered following the bankruptcy of the New Century Financial Corporation on March 13, 2007. The U.S. subprime mortgage crisis was a tragic event that can be used by researchers to empirically test for contagion effects in financial markets.

Studies such as Baig and Goldfajn (1999), Edwards (2000), Bazdresch and Werner (2001), Gande and Parsley (2005), Arestis et al. (2005), Kallberg et al. (2002, 2005), Kuper and Lestano (2007),

\footnotetext{
* Corresponding author. E-mail: sharon0623@gmail.com
}

and Eddie and Ka (2012) demonstrated that financial markets are vulnerable to contagion effects. If uncontained, these contagion effects can lead to a dramatic loss of investor confidence, which in turn can cause instability in regional and global financial markets. This study conducted a crossmarket examination of the relationships between the stock market and the real estate investment trust (REIT) market to test the synchronization and integration of the two markets. Markets that observe strong comovements between stock and REIT prices are vulnerable to contagion effects. Increased correlations between financial markets across various countries signal strong economic convergence, which reduces the effectiveness of international diversification strategies. International investors must be mindful that asset return correlations are not constant. In addition, they must learn to manage contagion risks when cross-market asset return correlations increase considerably. 
Some researchers have discovered evidence of dynamic return correlations between stocks and REITs. Chandrashekaran (1999) calculated the correlation coefficients between the monthly excess returns of the REIT index and the S\&P 500. He demonstrated that the correlation dropped from $79 \%$ in $1980-1984$ to $48 \%$ in $1990-1996$. Clayton and MacKinnon (2001), Conover et al. (2002), Bley and Olson (2005), and Westerheide (2006) revealed that the correlations between REITs and stocks declined during the period from 1972 to 2001. Cotter and Stevenson (2006) used a multivariate vector autoregressive generalized autoregressive conditional heteroskedasticity (VAR-GARCH) technique to model the daily return and volatility relationships between REITs that specialize in various property types and between the REITs and stocks. That study demonstrated that the daily conditional correlations fluctuated widely, but trended upward during the period from January 1999 to June 2003. None of these studies, however, tested the contagion effects between the stock market and the REIT market.

Contagion risk is a topic of contention in financial literature. Forbes and Rigobon (2002) define contagion as a considerable increase in comovements across markets. A persistently high correlation suggests strong linkages between two economies (markets) that are said to be interdependent. Based on this argument, contagion is signified by a dynamic increase in the correlation. This study tests for contagion effects across various asset classes (stocks and REIT) and various markets. Two methodologies are used in our tests. First, the constant conditional correlation model of Bollerslev (1990) and the dynamic conditional correlation (DCC) model of Engle (2002) are used to estimate the time-varying beta. Second, the study estimates the downside systematic risks for the REIT markets to more reliably capture the risk preference of investors. Investors are more sensitive to downside losses than to upside gains. They expect a premium on holding assets that strongly correlate with declining markets (Ang et al. 2006). Young (2008) and Yang and Chen (2009) showed that REIT return distributions are not normal, but are rather peaked with fat tails.

We estimate four time-varying beta measures: (a) the traditional CAPM beta; (b) Hogan and Warren's (1974) HW-beta, which sets the target returns below the risk-free rate; (c) Harlow and Rao's (1989) HR-beta, which relates the target rates to the mean-equity market returns; and (d) Estrada's (2002) E-beta, which considers returns on equity and market portfolios that fall below their respective means. By using the rolling method and the DCC model, we estimate and use the betas in our tests for contagion effects in the markets.

This study offers three contributions to the literature. First, it uses a DCC-GARCH $(1,1)$ model to analyze the time-varying betas for seven REIT markets across Europe, Asia, Oceania, and the U.S. We demonstrate that REIT markets in the European Union possess higher systematic and downside risks than do other markets. By contrast, systematic risks in Japanese and Australian REIT markets are relatively low. Investors can use Japanese and Australian REITs to hedge against investment risks in their portfolios. Second, we estimate four different betas and independently test their relationships with the expected returns in each sample market. The results reveal that the DCC E-beta captures the downside linkages between market portfolios and expected stock returns. Third, we use the DCC with a multivariate GJR-GARCH $(1,1)$ model to evaluate the contagion effects that occurred across various economic regions during the U.S. subprime mortgage crisis. The synchronization and integration of the global financial markets may have facilitated the spread of the contagion of the crisis to other countries.

The rest of the paper is organized as follows. Section 2 discusses the empirical methodology, which includes DCC and downside risk beta measures. Section 3 covers the data sources and analyses. Section 4 presents the empirical results and draws relevant inferences from them. Section 5 concludes the study with highlights of the major findings and limitations.

\section{EMPIRICAL METHODOLOGY}

\subsection{DCC}

Asymmetric volatilities, volatility persistence, and return autocorrelations are factors generating time-varying correlations in asset returns. We use the DCC model of Engle (2002) to estimate the dynamic correlations between stock markets and the conditional (downside) beta for each national market.

Based on Engle (2002), the returns can either possess means of zero or be the residuals from a filtered time series, expressed as follows:

$$
r_{t} \sim N\left(0, H_{t}\right)
$$

and

$$
H_{t} \equiv D_{t} R_{t} D_{t},
$$


where: $D_{t}$ is the $\mathrm{k} \times \mathrm{k}$ diagonal matrix of the timevarying standard deviations from the univariate GARCH model, with $\sqrt{h_{i t}}$ on the $i^{\text {th }}$ diagonal and $R_{t}$ as the time-varying correlation matrix. The log likelihood of this estimator is expressed as follows:

$$
\begin{aligned}
& L=-\frac{1}{2} \sum_{t=1}^{T}\left(k \log (2 \pi)+2 \log \left|H_{t}\right|+r_{t}^{\prime} H_{t}^{-1} r_{t}\right)= \\
& -\frac{1}{2} \sum_{t=1}^{T}\left(k \log (2 \pi)+2 \log \left|D_{t} R_{t} D_{t}\right|+r_{t}^{\prime} D_{t}^{-1} R_{t}^{-1} D_{t}^{-1} r_{t}\right)= \\
& -\frac{1}{2} \sum_{t=1}^{T}\left(k \log (2 \pi)+2 \log \left|D_{t}\right|+\log \left(\left|R_{t}\right|+\varepsilon_{t}^{\prime} R_{t}^{-1} \varepsilon_{t}\right),\right.
\end{aligned}
$$

where: $\varepsilon_{t} \sim N\left(0, R_{t}\right)$ are the residuals standardized by the conditional standard deviation.

Engle (2002) proposed expressing the elements of $D_{t}$ as univariate GARCH models to yield the following:

$$
h_{i t}=\omega_{i}+\sum_{p=1}^{p_{i}} \alpha_{i p} \gamma_{i t-p}^{2}+\sum_{q=1}^{Q_{i}} \beta_{i q} h_{i t-q},
$$

where: $i=1,2, \ldots, \mathrm{k}$, with the usual GARCH restrictions for non-negativity and stationary being imposed (non-negativity of variances and $\left.\sum_{p=1}^{P_{i}} \alpha_{i p}+\sum_{q=1}^{Q_{i}} \beta_{i q}<1\right)$. The subscripted $p$ s and $q$ s of each series indicate that the lag lengths need not be the same. The proposed dynamic correlation structure is then generated as follows:

$Q_{t}=\left(1-\sum_{m=1}^{M} \alpha_{m}-\sum_{n=1}^{N} \beta_{n}\right) \bar{Q}+\sum_{m-1}^{M} \alpha_{m}\left(\varepsilon_{t-m} \varepsilon_{t-m}^{\prime}\right)+\sum_{n=1}^{N} \beta_{n} Q_{t-n} ;$

$$
R_{t}=Q_{t}^{*}-1 Q_{t} Q_{t}^{*}-1
$$

where: $\bar{Q}$ is the unconditional covariance of the standardized residuals resulting from the univariate GARCH equation, and $Q_{t}^{*}$ is a diagonal matrix composed of the square root of the diagonal elements of $Q_{t}$. This can be expressed as follows:

$$
Q_{t}^{*}=\left[\begin{array}{cccc}
\sqrt{q_{11}} & 0 & \cdots & 0 \\
0 & \sqrt{q_{22}} & \cdots & 0 \\
\vdots & \vdots & \vdots & 0 \\
0 & 0 & \cdots & \sqrt{q_{k k}}
\end{array}\right] .
$$

The typical element of $R_{t}$ is in the form $\rho_{i j t}=\frac{q_{i, j, t}}{\sqrt{q_{i i, t} q_{j j, t}}}$, and the matrix $R_{t}$ is a positive definite. The $K$ asset covariance matrix, $H_{t}$, is thus a positive definite and can be written as $H_{t} \equiv D_{t} R_{t} D_{t}$.

\subsection{The CAPM and downside betas}

\subsubsection{Traditional measures of the CAPM and downside betas}

This study focuses on the systematic risk associated with second moments. Therefore, our discussion is limited to the CAPM and downside betas. The CAPM beta is denoted by $\beta_{i t}^{C A P M}$ and is produced by the following:

$$
\beta_{i t}^{C A P M}=\frac{\operatorname{Cov}\left[\left(R_{i t}-R_{f}\right) \cdot\left(R_{M t}-R_{f}\right)\right]}{\operatorname{Var}\left[\left(R_{M t}-R_{f}\right)\right]},
$$

where: $R_{i t}$ and $R_{M t}$ are the returns of security $i$ ( $i=$ $1,2, \ldots, 14)$ and the market portfolio $M$, respectively, at time $t$; and $R_{f}$ is the risk-free rate. Therefore, $\left[R_{i t}-R_{f}\right]$ denotes the abnormal return of security $i$, and $\left[R_{M t}-R_{f}\right]$ denotes the excess return of the market portfolio. The CAPM beta is a combination of covariance and volatility that measures both the sensitivity of asset returns to market returns and the correlated relative volatility.

This study considers three measures of the downside beta that have been proposed in the literature. The first was proposed by Hogan and Warren (1974). Considering a riskless asset to be an opportunity cost in their interpretation of the CAPM in a downside framework, they defined the downside beta (HW-beta), denoted by $\beta_{i t}^{H W}$, as follows:

$$
\beta_{i t}^{H W}=\frac{\operatorname{Cov}\left[\left(R_{i t}-R_{f}\right) \cdot \min \left(R_{M t}-R_{f}, 0\right)\right]}{\operatorname{Var}\left[\min \left(R_{M t}-R_{f}, 0\right)\right]} .
$$

The numerator in Equation (9) is referred to as the cosemivariance of the market portfolio's returns below $R_{f t}$ with the returns in excess of $R_{f t}$ on security $i$.

Harlow and Rao (1989) suggested that investors characterize risk as downside deviations below a target set by mean-equity market returns rather than by the risk-free rate. Therefore, they calculated the downside beta (HR-beta) using the covariance of the returns below the average return of the market portfolio and the de-meaned return on security $i$. The HR-beta, denoted by $\beta_{i t}^{H R}$, can thus be expressed as follows:

$$
\beta_{i t}^{H R}=\frac{\operatorname{Cov}\left[\left(R_{i t}-\mu_{i}\right) \cdot \min \left(R_{M t}-\mu_{M}, 0\right)\right]}{\operatorname{Var}\left[\min \left(R_{M t}-\mu_{M}, 0\right)\right]},
$$

where: $\mu_{i}$ and $\mu_{M}$ are the average returns of security $i$ and the market portfolio $M$, respectively.

Estrada (2002) modified the HR-beta in a downside framework by defining the covariance of re- 
turns of security $i$ with those of the market portfolio as $\operatorname{Cov}\left[\min \left(R_{i t}-\mu_{i}, 0\right) \cdot \min \left(R_{M t}-\mu_{M}, 0\right)\right]$. Generalizing the concept of correlation asymmetry, Estrada (2002) calculated the correlation of doubly truncated bivariate distributions and the downside beta (E-beta), denoted by $\beta_{i t}^{E}$, as follows:

$\beta_{i t}^{E}=\frac{\operatorname{Cov}\left[\min \left(R_{i t}-\mu_{i}, 0\right) \cdot \min \left(R_{M t}-\mu_{M}, 0\right)\right]}{\operatorname{Var}\left[\min \left(R_{M t}-\mu_{M}, 0\right)\right]}$.

Galagedera and Brooks (2007) showed that the E-beta focuses only on negative returns and thus "cannot be linked to a well-behaved utility function". However, the E-beta does not suffer from the measure-inconsistency problem, in which the covariance between securities $i$ and $j$ is not equal to the covariance between securities $j$ and $i$.

\subsubsection{The conditional CAPM beta (downside beta): using the DCC model}

It is well known that financial time-series data, in general, exhibit strong-volatility autocorrelation behavior (Koutmos 1999; Lebaron 1992), but some studies do not consider this property when estimating the CAPM beta. We use the DCC model to estimate the CAPM and three downside betas. The parameters of the DCC model are estimated in a two-step procedure. We first apply the GARCH model to remove the autocorrelation of the variance and then use the filtered series to estimate the DCC model. Having used the standardized residuals from the first step, we proceed with the second step of estimating the DCC model. This estimation produces time-varying conditional variances and conditional covariances. To avoid confusion with the previously mentioned empirical process, this study refers to the betas estimated by the DCC-GARCH model as the conditional CAPM and downside betas. The conditional CAPM provides a convenient method for incorporating both the timevarying conditional variances and covariances (Bodurtha, Mark 1991). The conditional CAPM and downside betas can be expressed as follows:

$$
\beta_{\mathrm{it}, \Omega_{\mathrm{t}-1}}^{C A P M}=\frac{\operatorname{Cov}\left[\left(R_{i t}-R_{f t}\right)\left(R_{M t}-R_{f t}\right) \mid \Omega_{t-1}\right]}{\operatorname{Var}\left[\left(R_{M t}-R_{f t}\right) \mid \Omega_{t-1}\right]},
$$

where: $\Omega_{t-1}$ represents the information set at time $t-1$. Similarly, the time-varying conditional downside betas are yielded by the following equations:

$$
\beta_{\mathrm{it}, \Omega_{\mathrm{t}-1}}^{H W}=\frac{\operatorname{Cov}\left[\left(\left(R_{i t}-R_{f t}\right) \cdot \min \left(R_{M t}-R_{f t}, 0\right)\right) \mid \Omega_{t-1}\right]}{\operatorname{Var}\left[\min \left(R_{M t}-R_{f t}, 0\right) \mid \Omega_{t-1}\right]},
$$

$\beta_{\mathrm{it}, \Omega_{\mathrm{t}-1}}^{H R}=\frac{\operatorname{Cov}\left[\left(\left(R_{i t}-\mu_{i t}\right) \cdot \min \left(R_{M t}-\mu_{M t}, 0\right)\right) \mid \Omega_{t-1}\right]}{\operatorname{Var}\left[\min \left(R_{M t}-\mu_{M t}, 0\right) \mid \Omega_{t-1}\right]}$

and

$$
\beta_{\mathrm{it}, \Omega_{\mathrm{t}-1}}^{E}=\frac{\operatorname{Cov}\left[\left(\min \left(R_{i t}-\mu_{i t}, 0\right) \cdot \min \left(R_{M t}-\mu_{M t}, 0\right)\right) \mid \Omega_{t-1}\right]}{\operatorname{Var}\left[\min \left(R_{M t}-\mu_{M t}, 0\right) \mid \Omega_{t-1}\right]} .
$$

\section{DATA AND DESCRIPTIVE STATISTICS}

This study considered seven REIT markets, including the global, United States, European Union, Japanese, Hong Kong, Singapore, and Australian markets. The selected data periods span the events of the financial crisis. The samples start on January 3, 2000; January 2, 2002; April 2, 2002; and March 1, 2005. The sample end date is June 30, 2013. All data were collected from the Bloomberg database. When data were unavailable because of holidays or other reasons, the REITs and stock prices were assumed to be identical to those of the previous trading day.

In addition, calculating the beta (the conventional measure of systematic risk) is crucial for selecting the market portfolio. The MSCI world index, which covers approximately 8,500 securities of various sizes, is used here as the proxy for the market index. It consists of 45 national indices from 24 developed and 21 emerging-market countries. By capturing the global-equity investmentopportunity set, the MSCI world index can be used as a broad and investable global-equity benchmark for asset allocation. Finally, the yields on threemonth U.S. Treasury bills over the same periods are used as proxies for the risk-free rate, the nominal data of which had also been converted to a daily interest rate.

Based on the conventional approach, the REIT and stock returns are calculated as the first difference of the natural log of each price index, and the returns are expressed as percentages. The summary statistics of the REIT- and stock-index returns are presented in Table 1 . To visualize the returns for each market, we depict the series in Figure 1, which shows a clustering of high return volatility. This market phenomenon has been widely recognized and successfully captured by GARCH models in the finance literature (Bollerslev et al. 1992).

Table 1 reveals that the minimum daily returns of the nine markets range from $-21.53 \%$ to $-7.32 \%$ and that the maximum returns range from $7.71 \%$ to $19.73 \%$. The skewness ranged from -0.7641 to 0.1041. Finally, the Global REIT Index return distribution is negatively skewed and exhibits an 
excess kurtosis of 6.7474 and a mean return of $0.0375 \%$.

As noted in various media reports, the New Century Financial Corporation, the second-largest U.S. subprime mortgage company that filed for bankruptcy, ignited the subprime mortgage crisis on March 13, 2007. Therefore, we use this date to divide the sample into two subperiods: pre-crisis and post-crisis. Because of the data availability, the sample of the pre-crisis period is only 2 years. Therefore, we consider two kinds of post-crisis periods: one includes only the sample period of 2 years (from March 13, 2007 to March 12 , 2009) for comparison, and the other includes all sample periods (from March 13, 2007 to June $30,2013)$ to examine the long-term effect. The summary statistics of the REIT returns in the seven-market subsample are presented in Table 2 .

Table 1. Descriptive statistics on stock returns and REIT returns

\begin{tabular}{llllllll}
\hline Items & Mean & Max & Min & Std. Dev. & Skewness & Kurtosis & Starting date \\
\hline \multicolumn{2}{l}{ Panel A: the stock market } & & & & & \\
S\&P 500 & 0.0026 & 10.9572 & -9.4695 & 1.3283 & -0.1680 & 4.5715 & 3-Jan-00 \\
MSCI & 0.0003 & 9.0977 & -7.3221 & 1.1194 & -0.3412 & 2.8874 & 3-Jan-00 \\
Panel B: the REIT market & & & & & \\
Global & 0.0375 & 7.7128 & -9.7304 & 1.1831 & -0.5930 & 6.7474 & 3-Jan-00 \\
US & 0.0250 & 16.8755 & -21.5324 & 2.0366 & -0.1916 & 14.1588 & 3-Jan-00 \\
EU & 0.0045 & 8.5751 & -10.1439 & 1.7153 & -0.3572 & 1.0828 & 1-Mar-05 \\
JP & 0.0128 & 10.6370 & -12.7756 & 1.5269 & -0.4455 & 7.4984 & 1-Apr-02 \\
HK & 0.0120 & 19.7289 & -19.0823 & 1.8952 & 0.0311 & 5.6083 & 3-Jan-00 \\
SG & 0.0018 & 12.5791 & -15.2938 & 1.7579 & 0.1041 & 3.3552 & 3-Jan-00 \\
AU & -0.0077 & 8.1115 & -11.2176 & 1.4360 & -0.7641 & 6.1593 & 2-Jan-02 \\
\hline
\end{tabular}

Table 2. Descriptive statistics of the REIT returns (subsample)

\begin{tabular}{|c|c|c|c|c|c|c|}
\hline Items & Mean & $\operatorname{Max}$ & Min & Std. Dev. & Skewness & Kurtosis \\
\hline \multicolumn{7}{|c|}{ Panel A: pre-Subprime mortgage crisis (3/13/2005-3/12/2007) } \\
\hline Global & 0.1152 & 2.3059 & -3.5340 & 0.6894 & -0.4662 & 5.0313 \\
\hline US & 0.0863 & 3.3657 & -3.7305 & 0.9647 & -0.2729 & 4.1168 \\
\hline EU & 0.1163 & 4.1849 & -3.9322 & 0.9605 & -0.0714 & 6.2504 \\
\hline JP & 0.0951 & 6.0302 & -4.6316 & 0.9384 & 0.2483 & 9.0382 \\
\hline HK & 0.1513 & 19.7289 & -4.4053 & 1.4238 & 4.9476 & 73.9423 \\
\hline SG & 0.1525 & 5.5992 & -5.4087 & 1.2435 & -0.3559 & 5.7634 \\
\hline $\mathrm{AU}$ & 0.0660 & 3.1338 & -2.9548 & 0.8179 & -0.0615 & 4.0701 \\
\hline \multicolumn{7}{|c|}{ Panel B: post-Subprime mortgage crisis (3/13/2007-3/12/2009) } \\
\hline Global & -0.2171 & 7.7128 & -9.7304 & 2.0762 & -0.3889 & 6.0127 \\
\hline US & -0.2233 & 16.8755 & -21.5324 & 3.9387 & -0.1061 & 7.6937 \\
\hline EU & -0.2663 & 7.4691 & -10.1439 & 2.4059 & -0.2889 & 4.9062 \\
\hline JP & -0.2210 & 10.6370 & -12.7756 & 2.6481 & -0.1961 & 6.2144 \\
\hline HK & -0.1032 & 10.4649 & -10.4670 & 2.7197 & -0.1231 & 5.1757 \\
\hline $\mathrm{SG}$ & -0.2307 & 12.5791 & -10.3180 & 2.4388 & 0.3664 & 6.1887 \\
\hline $\mathrm{AU}$ & -0.2493 & 8.1115 & -11.2176 & 2.6377 & -0.4829 & 5.1671 \\
\hline \multicolumn{7}{|c|}{ Panel C: post-Subprime mortgage crisis (3/13/2007-6/30/2013) } \\
\hline Global & -0.0032 & 7.7128 & -9.7304 & 1.5565 & -0.3929 & 2.5321 \\
\hline US & -0.0096 & 16.8755 & -21.5324 & 2.8103 & -0.1042 & 5.7202 \\
\hline EU & -0.0298 & 8.5751 & -10.1439 & 1.8918 & -0.3075 & 0.1496 \\
\hline JP & -0.0319 & 10.6370 & -12.7756 & 1.8327 & -0.3551 & 4.2186 \\
\hline HK & 0.0056 & 10.4649 & -10.4670 & 1.9625 & 0.0082 & 0.3986 \\
\hline $\mathrm{SG}$ & -0.0284 & 12.5791 & -10.3180 & 1.7438 & 0.3093 & 3.3025 \\
\hline $\mathrm{AU}$ & -0.0501 & 8.1115 & -11.2176 & 1.8184 & -0.6206 & 2.4066 \\
\hline
\end{tabular}



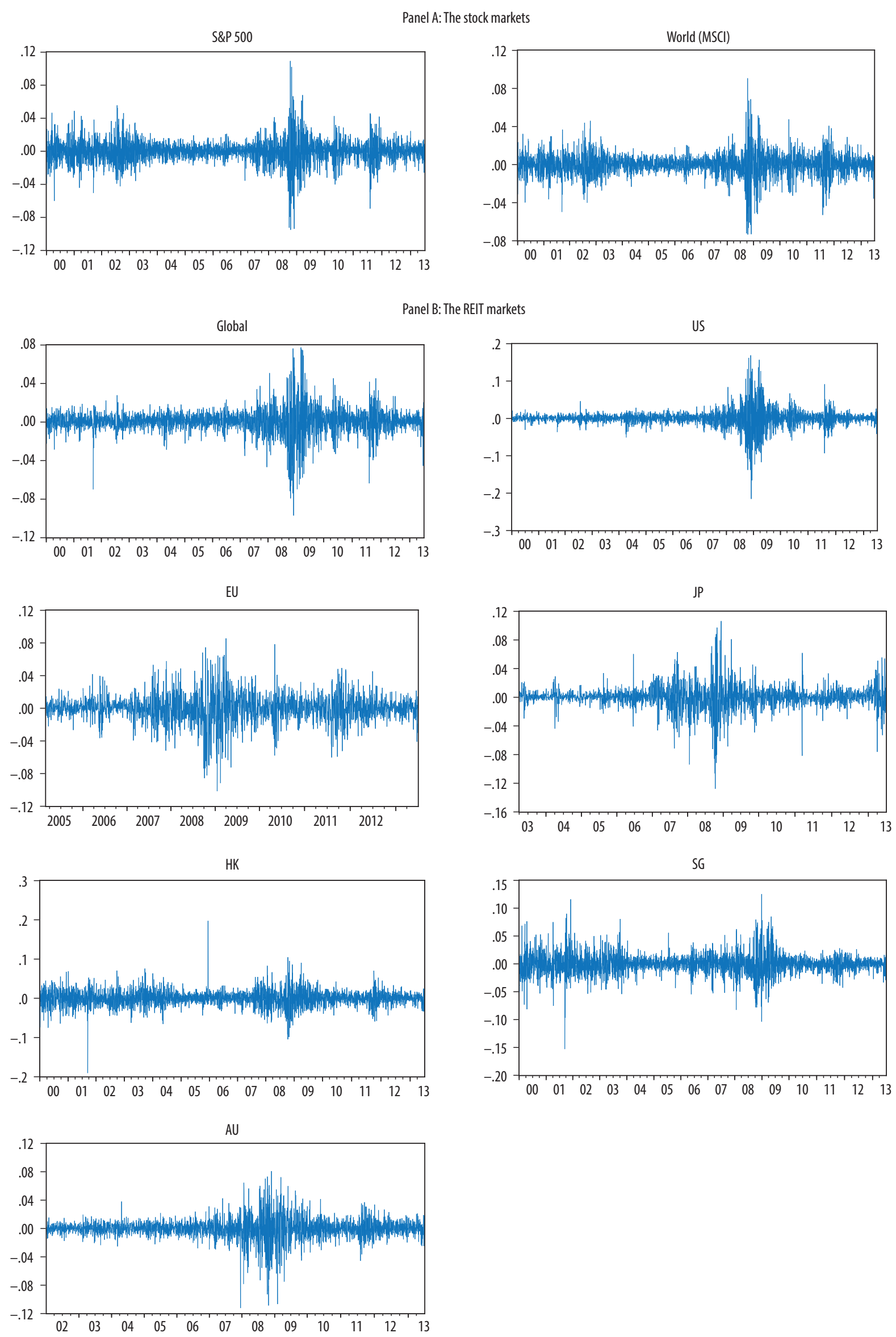

Fig. 1. Stock and REIT returns for each market over the sample period 
A comparison of the two subperiods reveals that the REIT returns are generally higher during the pre-crisis than during the post-crisis period, whereas the standard deviations are higher during the post-crisis than during the pre-crisis period.

All markets exhibited positive average returns during the pre-crisis periods, with the Singapore market exhibiting the highest average daily return $(0.1525 \%)$ and the Australian market the lowest $(0.0660 \%)$. The Hong Kong market possessed the highest standard deviation, whereas the global index return exhibited the lowest. The minimum daily returns fell within the range of $-5.4087 \%$ and $-2.9548 \%$, and the maximum returns ranged between $2.3059 \%$ and $19.7289 \%$. The distributions of most of the markets returns were negatively skewed. In the post-crisis period (from March 13, 2007 to March 12, 2009), all markets exhibited negative average returns. It should be noted that the European market possessed the lowest average return $(-0.2663 \%)$, which suggests that it was the most severely affected market during the crisis period. The minimum daily return ranged from $-21.5324 \%$ to $-9.7304 \%$, whereas the maximum varied between $7.4691 \%$ and $16.8755 \%$.

\section{EMPIRICAL RESULTS}

\subsection{Contagion effects between the stock and REIT markets}

The contagion effect is an adverse condition which arises when one company negatively affects other companies or an entire industry. Contagion effects on a broader scale can also be a market concern. Contagion effects may spread from one country to another and consequentially affect the entire global market.

Forbes and Rigobom (2002) define contagion as a major increase in comovement across markets.
Thus, the contagion involves an increase in dynamic correlations. This study uses the DCC of Engle with a multivariate GJR-GARHC $(1,1)$ model to estimate DCCs. Table 3 presents the parameter estimates for the GJR-GARCH $(1,1)$ model. The results show that all of the "beta" and "gamma" parameters are significant, which implies that autocorrelation and asymmetry are demonstrated in most of the series. Therefore, the DCC used in conjunction with the GJR-GARCH $(1,1)$ model is suitable for estimating the conditional correlations between the stock and REIT markets.

Table 4 presents the summary statistics of the DCCs between the S\&P 500 and each REIT market. All conditional correlations between stock and REIT markets were positive, indicating that significant comovement existed between them. We used the S\&P 500 and U.S. REITs to illustrate this point because they possessed the highest correlation coefficients. The mean conditional correlation coefficient was 0.7540 . The highest conditional correlation was 0.8647 and the lowest conditional correlation was 0.5700 .

Figure 2 shows the individual DCC plots for the pairwise markets. The breakpoint dates are represented by the shaded area. All of the plots exhibit time-varying patterns with volatility clustering, which justifies the time-varying perspective of this study. Moreover, Figure 2 reveals swiftly rising time-varying conditional correlations between the S\&P 500 and each REIT market before the subprime mortgage crisis occurred. This phenomenon seems to indicate that financial markets typically respond early to market information or news, which supports the efficient market hypothesis.

To identify the existence of contagion, we use a $t$-test for the difference in the means of the DCC between the pre-crisis and the post-crisis periods.

Table 3. The parameter estimates of the GJR-GARCH $(1,1)$ (sample period: 3/13/2005-6/30/2013)

\begin{tabular}{|c|c|c|c|c|c|c|c|c|c|}
\hline \multirow{3}{*}{ S\&P500 } & \multicolumn{3}{|c|}{ ARCH(Alpha) } & \multicolumn{3}{|c|}{ GARCH(Beta) } & \multicolumn{3}{|c|}{ GJR(Gamma) } \\
\hline & Coefficient & & Std. Error & Coefficient & & Std. Error & Coefficient & & Std. Error \\
\hline & -0.0346 & $* * *$ & 0.0101 & 0.9271 & $* * *$ & 0.0145 & 0.1785 & $* * *$ & 0.0300 \\
\hline Global REITs & 0.0284 & $* *$ & 0.0132 & 0.9063 & $* * *$ & 0.0133 & 0.1116 & $* * *$ & 0.0242 \\
\hline US REITs & 0.0762 & $* * *$ & 0.0185 & 0.8819 & $* * *$ & 0.0145 & 0.0772 & $* * *$ & 0.0246 \\
\hline EU REITs & 0.0302 & $* *$ & 0.0129 & 0.9108 & $* * *$ & 0.0138 & 0.0964 & $* * *$ & 0.0202 \\
\hline JP REITs & 0.1456 & $* * *$ & 0.0286 & 0.8096 & $* * *$ & 0.0311 & 0.0978 & $* *$ & 0.0448 \\
\hline HK REITs & 0.0000 & & 0.0030 & 0.9552 & $* * *$ & 0.0104 & 0.0765 & $* * *$ & 0.0125 \\
\hline SG RETIs & 0.0631 & $* * *$ & 0.0216 & 0.8851 & $* * *$ & 0.0269 & 0.0721 & $* * *$ & 0.0255 \\
\hline AU REITs & 0.0474 & $* *$ & 0.0202 & 0.9082 & $* * *$ & 0.0250 & 0.0689 & $* * *$ & 0.0241 \\
\hline
\end{tabular}

Note: Asterisks denote statistical significance at the $1 \%\left({ }^{* * *}\right), 5 \%\left(^{(* *}\right)$, and $10 \%(*)$ levels. 
The test results for the contagion effects are presented in Table 5. The test results indicate that for each pair of stock and REIT markets, a significant increase occurred in the DCCs during the postcrisis period (March 13, 2007 to March 12, 2009). When we focus on the extended post-crisis period (March 13, 2007 to June 30, 2013), most markets, in addition to Hong Kong, also showed a significant increase. The results do not rule out the existence of a contagion effect in the REIT markets, because the impact of the subprime mortgage crisis persisted. Following the bankruptcy of Lehman Brothers, this impact could not be contained at the local level, and it quickly spread, then escalated into a global financial crisis.

The contagion effect implies integration and strong comovements between markets, which can reduce opportunities for international diversification. Increased correlations among financial markets may signal increased economic convergence. Investors must reduce investment risk by using hedging products, such as increasing bond allocation, shorting futures contracts, purchasing put options, and improving cash positions.

\subsection{Estimating the CAPM and downside betas}

As described in Section 4.1, the evidence for the contagion effect between the stock and REIT markets implies that the REIT markets may be exposed to greater systematic risk than other markets are. Therefore, this section focuses on the measure of systematic risk. First, using the formulae provided in Equations (8)-(11), we calculated the CAPM and three downside betas for each REIT market by using the standard rolling one-year daily return. For example, we used the REIT data of the United States from January 3, 2000 to January 1, 2001 to calculate the variance and covariance, which are provided in Equations (1)-(4), and then obtained the corresponding value as the beta of January 2, 1991.

Table 4. Dynamic conditional correlation (sample period: 3/13/2005-6/30/2013)

\begin{tabular}{llllll}
\hline & Mean & Median & Maximum & Minimum & Std. Dev. \\
\hline S\&P500-Global REITs & 0.7262 & 0.7278 & 0.8620 & 0.5443 & 0.0714 \\
S\&P500-US REITs & 0.7540 & 0.7612 & 0.8647 & 0.5700 & 0.0662 \\
S\&P500-EU REITs & 0.4879 & 0.5117 & 0.6813 & 0.2113 & 0.1006 \\
S\&P500-JP REITs & 0.2384 & 0.2276 & 0.5024 & 0.0535 & 0.0997 \\
S\&P500-HK REITs & 0.3270 & 0.3170 & 0.5565 & 0.0306 & 0.0997 \\
S\&P500-SG REITs & 0.3455 & 0.3461 & 0.5350 & 0.1090 & 0.0778 \\
S\&P500-AU REITs & 0.3494 & 0.3472 & 0.5431 & 0.0490 & 0.0916 \\
\hline
\end{tabular}

Table 5. Dynamic conditional correlation and contagion effect

\begin{tabular}{|c|c|c|c|c|}
\hline & pre-crisis mean & post-crisis mean & t-statistic & Conation effect \\
\hline \multicolumn{5}{|c|}{ Panel A: post-Subprime mortgage crisis (3/13/2007-3/12/2009) } \\
\hline S\&P500-Global REITs & 0.6555 & 0.7204 & $17.9105^{* * *}$ & Yes \\
\hline S\&P500-US REITs & 0.6814 & 0.7707 & $25.1371^{* * *}$ & Yes \\
\hline S\&P500-EU REITs & 0.3606 & 0.4632 & $23.1662^{* * *}$ & Yes \\
\hline S\&P500-JP REITs & 0.1466 & 0.3606 & $60.1964^{* * *}$ & Yes \\
\hline S\&P500-HK REITs & 0.3257 & 0.4466 & $26.8942^{* * *}$ & Yes \\
\hline S\&P500-SG REITs & 0.2979 & 0.4104 & $24.1964^{* * *}$ & Yes \\
\hline S\&P500-AU REITs & 0.2913 & 0.4128 & $38.2041^{* * *}$ & Yes \\
\hline \multicolumn{5}{|c|}{ Panel B: post-Subprime mortgage crisis (3/13/2007-6/30/2013) } \\
\hline S\&P500-Global REITs & 0.6555 & 0.7482 & $33.0185^{* * *}$ & Yes \\
\hline S\&P500-US REITs & 0.6814 & 0.7766 & $35.9015^{* * *}$ & Yes \\
\hline S\&P500-EU REITs & 0.3606 & 0.5274 & $45.3883^{* * *}$ & Yes \\
\hline S\&P500-JP REITs & 0.1466 & 0.2670 & $38.7670 * * *$ & Yes \\
\hline S\&P500-HK REITs & 0.3257 & 0.3274 & 0.3720 & NO \\
\hline S\&P500-SG REITs & 0.2979 & 0.3604 & $15.5366^{* * *}$ & Yes \\
\hline S\&P500-AU REITs & 0.2913 & 0.3675 & $25.6759 * * *$ & Yes \\
\hline
\end{tabular}

Note: Asterisks denote statistical significance at the $1 \%\left(^{* * *}\right), 5 \%(* *)$, and $10 \%(*)$ levels. 
a) CORR S\&P500 - Global REITs.

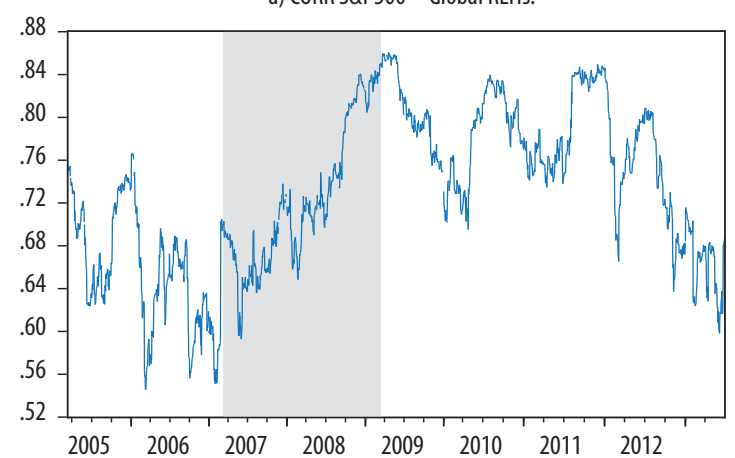

c) CORR S\&P500 - EU REITS.

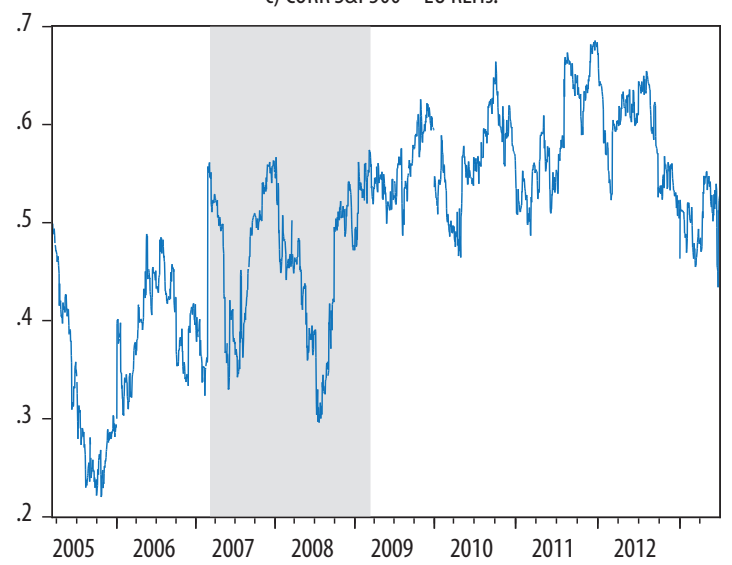

e) CORR S\&P500 - HK REITS.

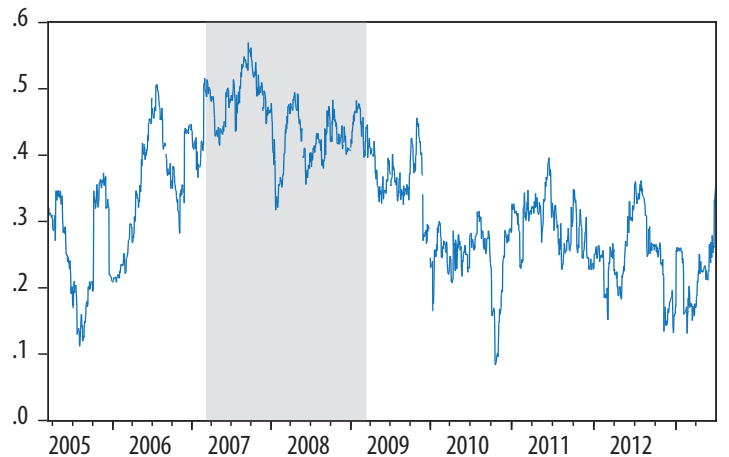

g) CORR S\&P500 - AU REITS.

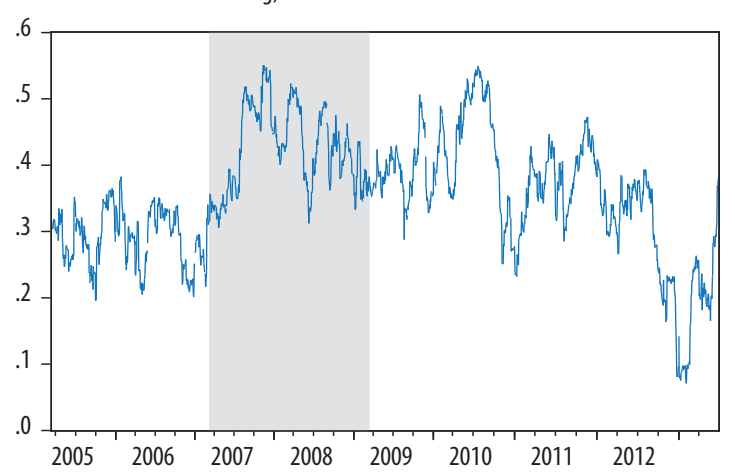

b) CORR S\&P500 - US REITS

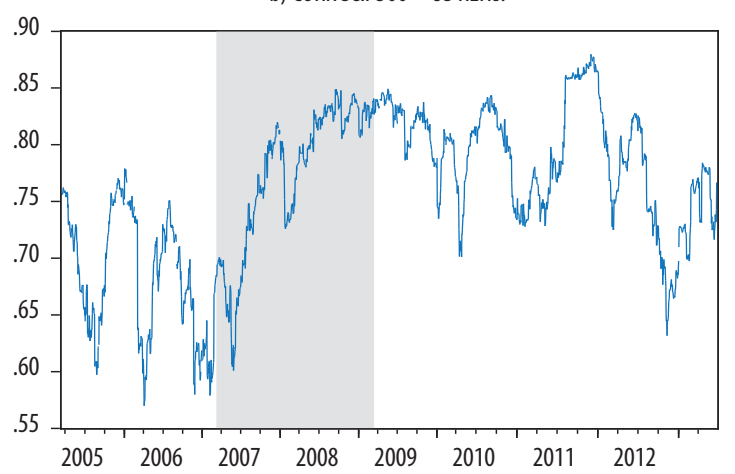

d) CORR S\&P500 - JP REITS.

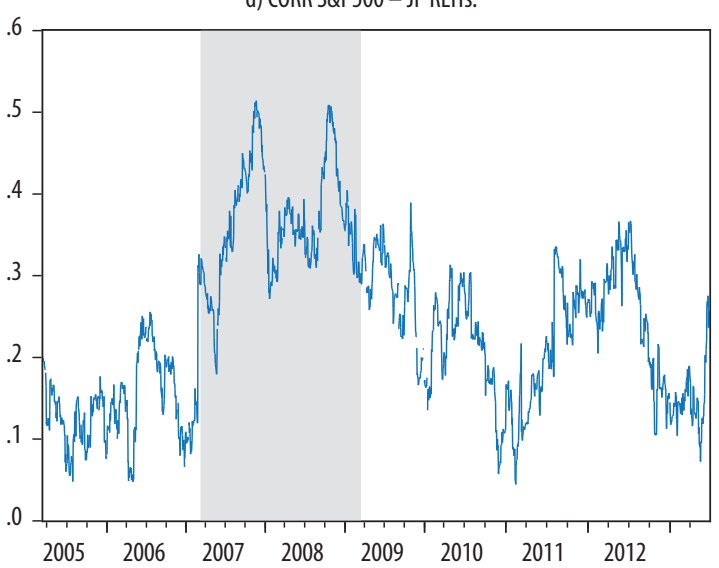

f) CORR S\&P500 - SG REITS

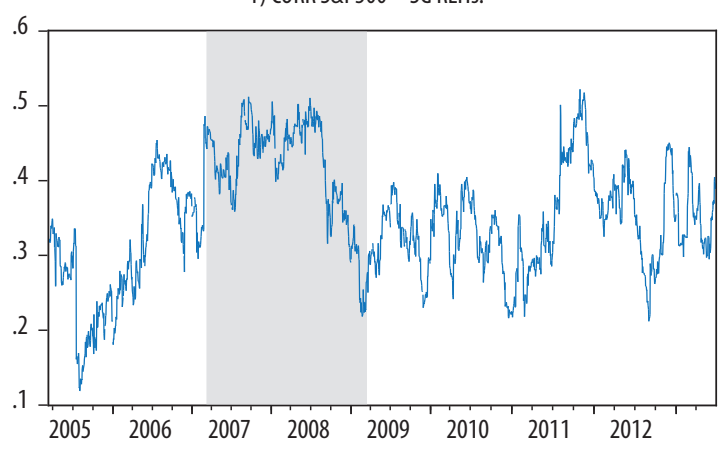

Note: The shaded area indicates the period of the subprime mortgage crisis from March 13, 2007 to March 12, 2009.

Fig. 2. The DCCs between the S\&P 500 and each REIT market 
This calculation rolled on daily to the end, producing a series of time-varying betas. To avoid confusion with the following empirical process, we refer to the beta estimated by the formula known as the "rolling beta." Second, considering most of the financial time-series data exhibits strong autocorrelation behavior, we used the DCC model to produce the time-varying conditional variance and conditional covariance. The DCC betas were estimated in a two-step procedure. We first applied the GARCH $(1,1)$ to remove serial correlation of variance and used the filtered series in estimating the DCC model. This estimation procedure uses the standardized residuals from the first step to produce the time-varying conditional variances and conditional covariances. Third, because Bodurtha and Mark (1991) suggested that the conditional CAPM provides a convenient way to incorporate the time-varying conditional variances and covariances, we directly used the conditional variances and conditional covariances as provided in Equations (12)-(15) and compute both the CAPM and three downside betas for each REIT market. To avoid confusion with this empirical process, we refer to the beta estimated by the DCC model as the "DCC beta".

Using the daily returns of seven REIT markets, we calculated the time-varying CAPM and three downside betas. To avoid redundancy, we depict the four types of time-varying rolling betas of the seven REIT markets in Figure 3. To illustrate the point, we use the United States as an example. Figure 3(b) provides the time-varying rolling betas of the U.S. market. The average CAPM beta is 0.972 . The highest beta (HR-beta) is 2.929 and the lowest beta (CAPM beta) is 0.310 . It is clear that all plots exhibit time-varying patterns with the volatility clustering, which justifies using the time-varying perspective in this study. In addition, this study reinforces the idea that a time-varying beta outperforms a constant beta (Harvey 1989; Ferson, Harvey 1991, 1993).

Table 6. The mean of time-varying beta (rolling-beta)

\begin{tabular}{lllll}
\hline $\begin{array}{l}\text { REIT } \\
\text { Market }\end{array}$ & $\begin{array}{l}\text { CAPM } \\
\text { beta }\end{array}$ & $\begin{array}{l}\text { HW } \\
\text { beta }\end{array}$ & $\begin{array}{l}\text { HR } \\
\text { beta }\end{array}$ & $\begin{array}{l}\text { E } \\
\text { beta }\end{array}$ \\
\hline Global & 0.8094 & 1.1324 & 1.1254 & 0.7796 \\
US & 0.9720 & 1.3251 & 1.3158 & 0.8841 \\
EU & 1.1694 & 1.5527 & 1.5514 & 1.0780 \\
JP & 0.3863 & 0.5409 & 0.5314 & 0.3953 \\
HK & 0.6177 & 0.8623 & 0.8445 & 0.5349 \\
SG & 0.4306 & 0.6358 & 0.6215 & 0.4429 \\
AU & 0.3812 & 0.5007 & 0.4927 & 0.3504 \\
\hline
\end{tabular}

To control the characteristics of autocorrelation behavior of stock returns, we employ the DCC model to produce the time-varying conditional variance and conditional covariance, and thus calculate the DCC beta. In Figure 4, we depict the four kinds of time-varying DCC betas of the seven REIT markets. Figure 4(b) shows that the average DCC CAPM beta for the U.S. REIT markets was 0.951 . The highest beta was 4.137 (DCC HR-beta) and the lowest beta was 0.131 (DCC E-beta).

To compare the CAPM and downside betas, the means of these time-varying betas are summarized in Tables 6 and 7. The results show that the European Union REIT market possessed the highest mean beta among the seven REIT markets, indicating a relatively high (downside) systematic risk in this region. The housing-market statistics for the European market revealed that residential permits grew at an annual rate of $4.11 \%$ to $-11.48 \%$ from October 2006 to 2007, indicating a sharp decline in production and new orders in the construction industry (the supply side). The data revealed early signs of a bubble in the European region before the U.S. subprime mortgage outbreak. By contrast, the systematic risks in Japanese and Australian REIT markets were relatively low. The low systematic risk in Australia is understandable because of its geographical location. In Japan, by comparison, because of the economic collapse, the Japanese market is gradually becoming less correlated with the world. Therefore, according to the results, investors and fund managers could choose Australian and Japanese REIT markets to hedge against risks.

We also plotted the means of the four types of rolling and DCC betas (in ascending order of CAPM beta) in Figure 5. The results show that the means of the HW-beta and HR-beta are always higher than the means of other betas, which could emphatically remind investors of the systematic risk involved in a downside market.

Table 7. The mean of time-varying conditional beta (DCC-beta)

\begin{tabular}{lllll}
\hline $\begin{array}{l}\text { REIT } \\
\text { Market }\end{array}$ & $\begin{array}{l}\text { CAPM } \\
\text { beta }\end{array}$ & $\begin{array}{l}\text { HW } \\
\text { beta }\end{array}$ & $\begin{array}{l}\text { HR } \\
\text { beta }\end{array}$ & $\begin{array}{l}\text { E } \\
\text { beta }\end{array}$ \\
\hline Global & 0.7629 & 1.0717 & 1.0662 & 0.7365 \\
US & 0.9510 & 1.3176 & 1.3096 & 0.8441 \\
EU & 1.1623 & 1.6041 & 1.5937 & 1.0967 \\
JP & 0.2039 & 0.3568 & 0.3518 & 0.2297 \\
HK & 0.6173 & 0.8831 & 0.8611 & 0.5302 \\
SG & 0.5048 & 0.8040 & 0.8013 & 0.5496 \\
AU & 0.4112 & 0.5457 & 0.5532 & 0.3584 \\
\hline
\end{tabular}



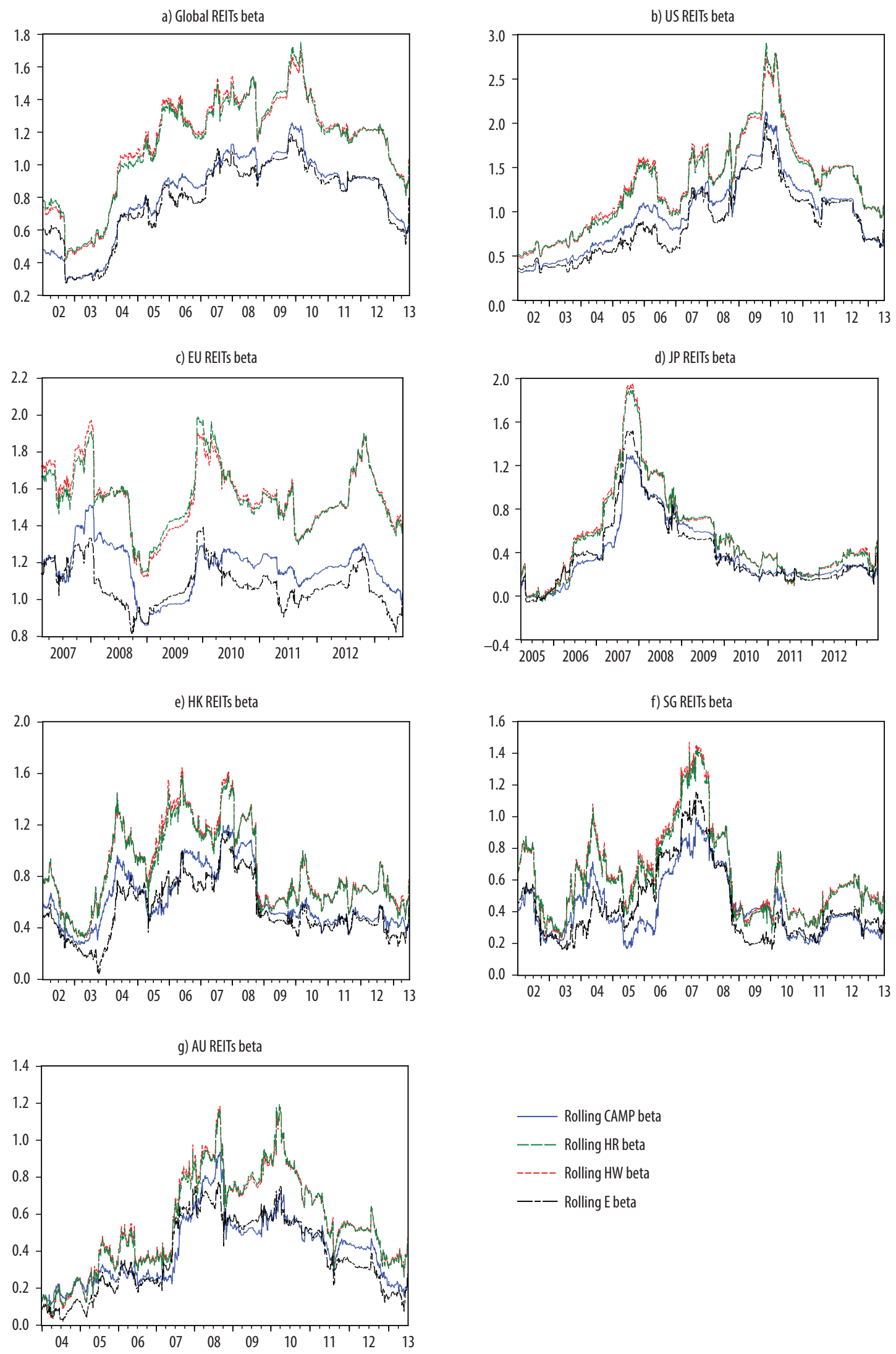

Fig. 3. The time-varying rolling CAPM beta and rolling downside betas 

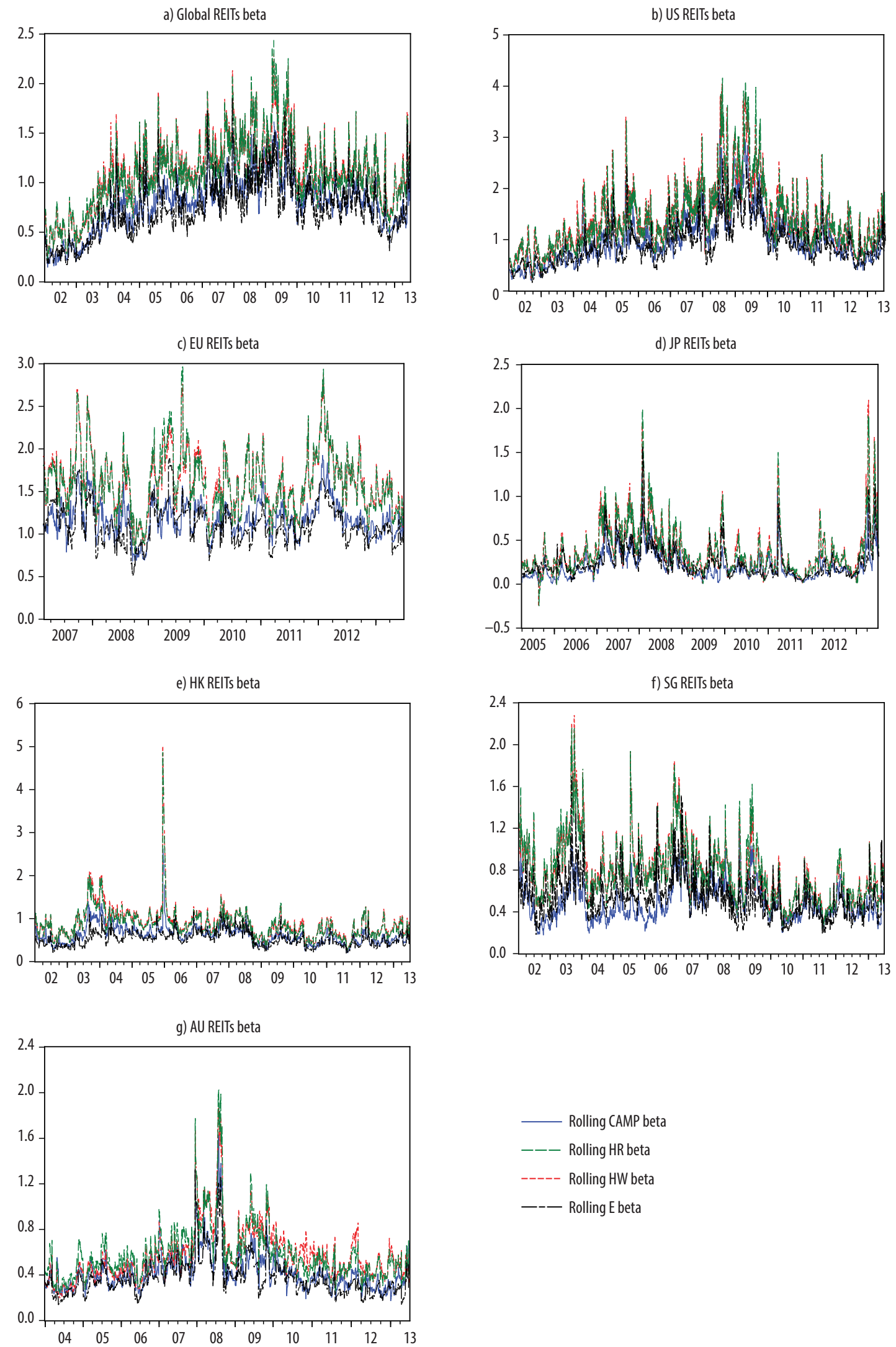

Fig. 4. The time-varying DCC CAPM and DCC downside betas 

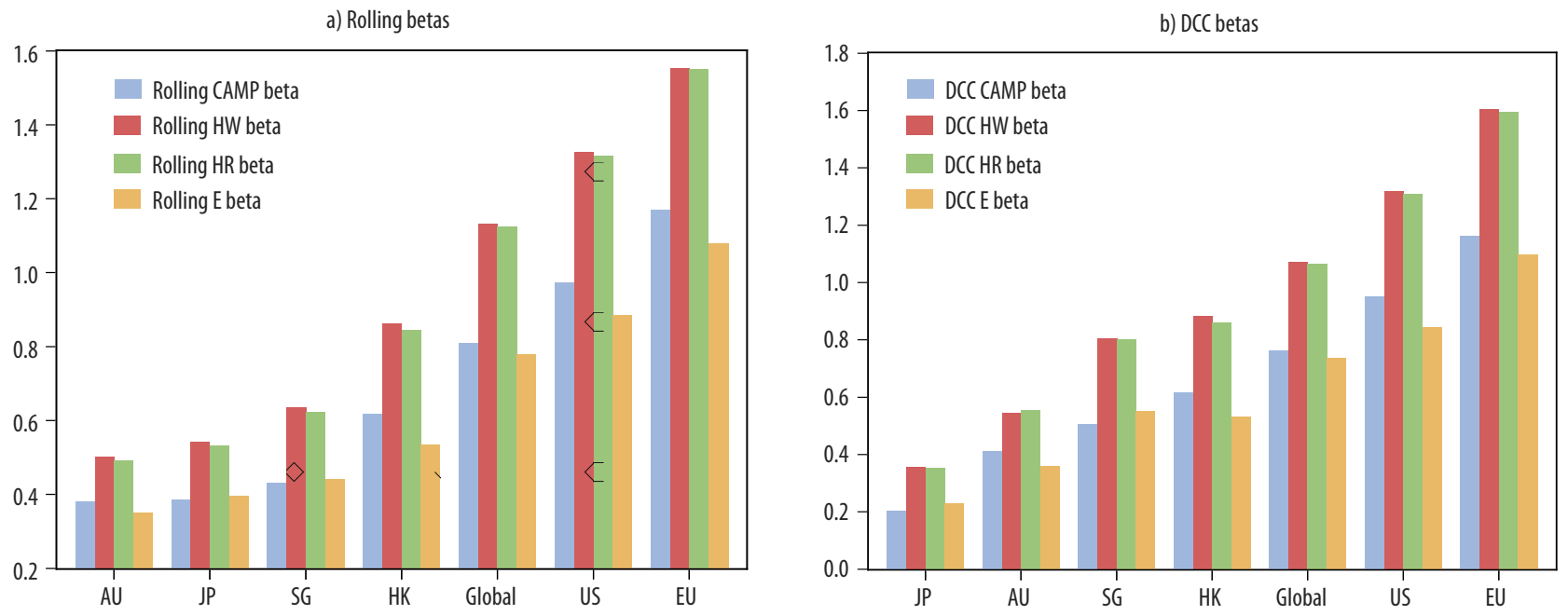

Fig. 5. The mean betas of seven REIT markets

The high values of the HW-beta and the HR-beta can indicate downside systematic risk when investors construct their investment portfolio. As seen in Figure 5, the results further reveal that the European Union REIT market possessed the highest betas among the seven REIT markets, indicating a relatively high (downside) systematic risk in this region. By contrast, the systematic risks in Japanese and Australian REIT markets were relatively low.

\subsection{Relationships between beta and expected REIT returns}

This study investigates the relationship between the DCC CAPM beta (the three downside betas) and the expected weekly REIT return for the subsample periods from March 13, 2007 to March 12, 2009 (i.e., after the subprime mortgage crisis). Tables 8 and 9 present the results of the regressions for the four types of betas and expected returns based on the rolling method and DCC model, respectively. As revealed in Table 8, most REIT market rolling betas did not significantly affect expected REIT returns. However, as shown in Table 9, it is clear that the DCC downside betas measure the relationship between risk and expected return more intuitively than the DCC CAPM beta. In the post-crisis period, the DCC downside betas possess significant positive effects on the expected REIT returns in most of the markets. In particular, the DCC E-beta is more reliable than the other betas for explaining the expected REIT market return. The positive effects on the expected REIT returns, as displayed in Table 9, are likely to be driven by the negative period of the financial crisis. The results are consistent with those demonstrated by Galagedera (2007). The primary explanatory power of the downside beta for the expected return reflects the view of investors, who are more sensitive to downside losses than to upside gains.

Table 8. The relationship between the rolling betas and the expected REIT return

\begin{tabular}{|c|c|c|c|c|c|c|c|c|}
\hline \multirow[t]{2}{*}{ REIT Market } & \multicolumn{2}{|c|}{ CAPM beta } & \multicolumn{2}{|l|}{ HW beta } & \multicolumn{2}{|l|}{ HR beta } & \multicolumn{2}{|l|}{ E beta } \\
\hline & $t$-statistic & & $t$-statistic & & $t$-statistic & & $t$-statistic & \\
\hline Global & -1.1235 & & -0.9838 & & -0.9958 & & -1.2067 & \\
\hline US & 0.1333 & & 0.1754 & & 0.1800 & & -0.1866 & \\
\hline EU & -0.5582 & & 0.3266 & & 0.5102 & & 1.0978 & \\
\hline JP & -2.0413 & $* *$ & -1.2171 & & -1.3103 & & -1.5712 & \\
\hline HK & -1.5692 & & -1.7906 & $*$ & -1.8438 & * & -1.8304 & * \\
\hline $\mathrm{SG}$ & -1.8958 & $*$ & -1.3458 & & -1.3831 & & -1.5724 & \\
\hline $\mathrm{AU}$ & -0.4683 & & -0.0062 & & -0.0785 & & 1.1925 & \\
\hline
\end{tabular}

Note: Asterisks denote statistical significance at the $1 \%\left({ }^{* * *}\right), 5 \%\left(^{* *}\right)$, and $10 \%\left({ }^{*}\right)$ levels. 
Table 9. The relationship between the DCC betas and the expected REIT return

\begin{tabular}{|c|c|c|c|c|c|c|c|c|}
\hline \multirow[t]{2}{*}{ REIT Market } & \multicolumn{2}{|c|}{ CAPM beta } & \multicolumn{2}{|c|}{ HW beta } & \multicolumn{2}{|c|}{ HR beta } & \multicolumn{2}{|l|}{ E beta } \\
\hline & \multicolumn{2}{|c|}{$t$-statistic } & \multicolumn{2}{|c|}{$t$-statistic } & \multicolumn{2}{|c|}{$t$-statistic } & \multicolumn{2}{|c|}{$t$-statistic } \\
\hline Global & 3.1840 & $* * *$ & 3.7717 & $* * *$ & 3.2630 & $* * *$ & 2.2101 & $* *$ \\
\hline US & -0.4541 & & 0.1137 & & -0.1220 & & -0.8035 & \\
\hline EU & 2.9787 & $* * *$ & 2.8537 & $* * *$ & 2.5321 & $* *$ & 2.5692 & $* * *$ \\
\hline JP & 3.6958 & $* * *$ & 4.5163 & & 4.5827 & $* * *$ & 4.2984 & $* * *$ \\
\hline HK & 1.6961 & $*$ & 1.1175 & & 0.7269 & & 2.5928 & $* * *$ \\
\hline $\mathrm{SG}$ & 1.0616 & & 2.3986 & $* *$ & 1.9518 & * & 3.9003 & $* * *$ \\
\hline $\mathrm{AU}$ & 3.7745 & $* * *$ & 2.8010 & & 3.5474 & $* * *$ & 4.3496 & $* * *$ \\
\hline
\end{tabular}

Note: Asterisks denote statistical significance at the $1 \%(* * *), 5 \%(* *)$, and $10 \%(*)$ levels.

\section{CONCLUSIONS}

Using the data periods before, during, and after the subprime-mortgage crisis, this study tested for contagion effects in the stock market and REIT markets by employing daily returns of seven REIT markets, including the global, United States, European Union, Japanese, Hong Kong, Singapore, and Australian markets. The data periods spanned the events of the subprime mortgage crisis. The empirical findings indicated a positive DCC coefficient between stock returns and REIT returns, and also revealed that the hypothesis of contagion effects between stock and REIT markets cannot be rejected. The variances were higher in the postcrisis period than in the pre-crisis period. The increases in the means of the DCC coefficients during the post-crisis periods provided considerable evidence for contagion effects.

In addition, the study used the rolling method and DCC-GARCH $(1,1)$ model to estimate the CAPM and three downside betas. We demonstrated that the European Union REIT markets possess the highest systematic risks (i.e., downside systematic risks) with beta values slightly above 1 . The REIT markets in Japan and Australia possessed relatively low systemic risks with the systematic risks (betas); they were estimated to be less than 0.5. The results suggested that Japanese and Australian REIT markets could provide a reliable hedge against systematic risks in the portfolios of investors and fund managers. By contrast, the high REIT betas for the United States and European Union did not typically appeal to conservative investors, such as retirement-fund investors, who prefer a stable and less volatile income stream than do ordinary investors.
This study estimated eight betas for each REIT market and examined the relationship between the estimated betas and the expected returns during the post-crisis periods. The results demonstrated that the DCC E-beta captures significant downside linkages between the expected REIT and market portfolio returns. These downside relationships are weakly captured by the CAPM beta.

The results of this study have several implications. First, if a crisis occurs in a huge economy such as the U.S., strong contagion effects can swiftly spread to other nations. The governments of the individual countries should take preventive measures to insulate their financial markets against these contagion effects. Some of these measures include developing flexible exchange rates, setting responsible fiscal policies, creating strong reserve levels, fostering an informed investment community, and implementing more reliable oversight of financial systems. These steps could reduce, if not fully eliminate, the spread of financial crises across borders. Furthermore, they can minimize the likelihood and potential intensity of any recurrence of financial contagion.

Second, systemic risk is a crucial factor for determining investor portfolio strategies. This study suggests that when building an investment portfolio during a financial crisis or an extreme event, investors should consider the time-varying downside systemic risks rather than the traditional CAPM systemic risk. The time-varying downside betas can offer investors a more effective measure of fund manager performance than can CAPM betas. In addition, corporate financial managers can use the downside time-varying beta to ensure that capital structure decisions are responsive to market dynamics. 
Finally, the empirical results of this study may help investors understand contagion effects and systematic risks in REIT markets during extreme financial events. The experience of the recent financial crisis may help to promote and cultivate considerable organizational and personal awareness of risk management. Building an effectively hedged investment portfolio can help avoid and minimize potential losses caused by systemic swings in returns in interconnected markets during periods of financial crisis.

\section{REFERENCES}

Ang, A.; Chen, J.; Xing, Y. 2006. Downside risk, Review of Financial Studies 19: 1191-1239. http://dx.doi. org/10.1093/rfs/hhj035

Arestis, P.; Caporale, G.; Cipollini, A. 2005. Testing for financial contagion between developed and emerging markets during the 1997 East Asian Crisis, International Journal of Finance and Economics 10(4): 359-367. http://dx.doi.org/10.1002/ijfe.284

Baig, T.; Goldfajn, I. 1999. Financial market contagion in the Asian crisis, International Monetary Fund (IMF) Staff Papers 46(2): 167-195.

Bazdresch, S.; Werner, A. M. 2001. Contagion of international financial crises: the case of Mexico, in Claessens, S.; Kristin J. Forbes, K. J. (Eds.). International financial contagion, Part III, 301-328. http://dx.doi. org/10.1007/978-1-4757-3314-3_12

Bley, J.; Olson. D. 2005. An analysis of relative return behavior: REITs vs. stocks, Academy of Accounting and Financial Studies Journal 9(2): 71-88.

Bodurtha, J.; Mark, N. 1991. Testing the CAPM with time-varying risk and returns, Journal of Finance 46: 1485-1505. http://dx.doi.org/10.1111/j.1540-6261. 1991.tb04627.x

Bollerslev, T. 1990. Modeling the coherence in short-run nominal exchange rates: a multivariate generalized ARCH model, Review of Economics and Statistics 72(3): 498-505. http://dx.doi.org/10.2307/2109358

Bollerslev, T.; Chou, R.; Kroner, K. 1992. ARCH modeling in finance, Journal of Econometrics 52: 5-59. http://dx.doi.org/10.1016/0304-4076(92)90064-X

Chandrashekaran, V. 1999. Time-series properties and diversification benefits of REIT returns, Journal of Real Estate Research 17(1/2): 91-112.

Clayton, J.; MacKinnon, G. 2001. The time-varying nature of the link between REIT, real estate and financial asset returns, Journal of Real Estate Portfolio Management 7(1): 43-54.

Conover, C. M.; Friday, H. S.; Sirmans, G. S. 2002. Diversification benefits from foreign real estate investments, Journal of Real Estate Portfolio Management 8(1): 17-25.

Cotter, J.; Stevenson, S. 2006. Multivariate modeling of daily REIT volatility, Journal of Real Estate Finance and Economics 32(3): 305-325. http://dx.doi. org/10.1007/s11146-006-6804-9
Eddie, C. M. H.; Ka, K. K. C. 2012. Are the global real estate markets contagious?, International Journal of Strategic Property Management 16(3): 219-235. http://dx.doi.org/10.3846/1648715X.2011.645904

Edwards, S. 2000. Contagion, World Economy 23(7): 873-900. http://dx.doi.org/10.1111/1467-9701.00307

Engle, R. F. 2002. Dynamic conditional correlation - a simple class of multivariate GARCH models, Journal of Business and Economic Statistics 20(3): 339-350. http://dx.doi.org/10.1198/073500102288618487

Estrada, J. 2002. Systematic risk in emerging markets: the D-CAPM, Emerging Markets Review 3(4): 365379. http://dx.doi.org/10.1016/S1566-0141(02)00042-0

Ferson, W.; Harvey, C. 1991. The variation of economic risk premiums, Journal of Political Economy 99: 385-415. http://dx.doi.org/10.1086/261755

Ferson, W.; Harvey, C. 1993. The risk of predictability of international equity returns, Review of Financial Studies 6: 527-566. http://dx.doi.org/10.1093/ $\mathrm{rfs} / 6.3 .527$

Forbes, K.; Rigobon, R. 2002. No contagion, only interdependence: measuring stock market comovements, Journal of Finance 57(5): 2223-2261. http://dx.doi. org/10.1111/0022-1082.00494

Galagedera, D. U. A. 2007. An alternative perspective on the relationship between downside beta and CAPM beta, Emerging Markets Review 8: 4-19. http://dx.doi. org/10.1016/j.ememar.2006.09.010

Galagedera, D. U. A.; Brooks, R. 2007. Is co-skewness a better measure of risk in the downside than downside beta? Evidence in emerging market data, Journal of Multinational Financial Management 17: 214-230. http://dx.doi.org/10.1016/j.mulfin.2006.10.001

Gande, A.; Parsley, D. C. 2005. News spillovers in the sovereign debt market, Journal of Financial Economics 75(3): 691-734. http://dx.doi.org/10.1016/j. jfineco.2003.11.003

Harlow, W. V.; Rao, R. K. S. 1989. Asset pricing in a generalized mean lower partial moment framework: theory and evidence, Journal of Financial and Quantitative Analysis 24: 285-311. http://dx.doi. org/10.2307/2330813

Harvey, C. 1989. Time-varying conditional covariance in tests of asset pricing models, Journal of Financial Economics 24: 289-317. http://dx.doi. org/10.1016/0304-405X(89)90049-4

Hogan, W. W.; Warren, J. M. 1974. Toward the development of an equilibrium capital market model based on semivariance, Journal of Financial and Quantitative Analysis 19: 1-11. http://dx.doi.org/10.2307/2329964

Kallberg, J. G.; Liu, C. H.; Pasquariello, P. 2002. Regime shifts in Asian equity and real estate markets, Real Estate Economics 30: 263-291. http://dx.doi. org/10.1111/1540-6229.00040

Kallberg, J. G.; Liu, C. H.; Pasquariello, P. 2005. An examination of the Asian crisis: regime shifts in currency and equity markets, Journal of Business 78(1): 169-211. http://dx.doi.org/10.1086/426523

Koutmos, G. 1999. Asymmetric price and volatility adjustments in emerging Asian stock markets, Journal of Business Finance and Accounting 26(1): 83-101. http://dx.doi.org/10.1111/1468-5957.00249 
Kuper, G. H.; Lestano. 2007. Dynamic conditional correlation analysis of financial market interdependence: an application to Thailand and Indonesia, Journal of Asian Economics 18(4): 670-684. http://dx.doi. org/10.1016/j.asieco.2007.03.007

Lebaron, B. 1992. Some relation between volatility and serial correlation in stock market returns, The Journal of Business 65: 199-219. http://dx.doi.org/10.1086/ 296565

Westerheide, P. 2006. Cointegration of real estate stocks and REITs with common stocks, bonds and consumer price inflation: an international comparison, $Z E W-$ Centre for European Economic Research Discussion Paper No. 06-057.

Yang, C. Y.; Chen, M. C. 2009. The role of co-kurtosis in the pricing of real estate, Journal of Real Estate Portfolio Management 15(2): 185-195.

Young, M. S. 2008. Revisiting non-normal real estate return distributions by property type in the U.S., Journal of Real Estate Finance and Economics 36: 233-248. http://dx.doi.org/10.1007/s11146-007-9048-4 